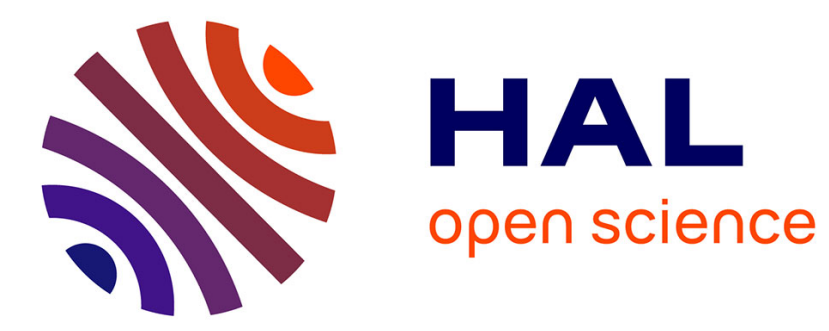

\title{
The human cultures in South-Eastern Caspian region in final Pleistocene - Holocene period
}

Solange Rigaud, Shnaider Svetlana, Alisher Kyzy Saltanat, Tamara Yanina, Bujilova Alexandra, Berezina Natalia, Rigaud Solange

\section{- To cite this version:}

Solange Rigaud, Shnaider Svetlana, Alisher Kyzy Saltanat, Tamara Yanina, Bujilova Alexandra, et al. The human cultures in South-Eastern Caspian region in final Pleistocene - Holocene period. Archaeological Research in Asia, 2021, 28, pp.100318. 10.1016/j.ara.2021.100318 . hal-03367388

\section{HAL Id: hal-03367388 \\ https://hal.science/hal-03367388}

Submitted on 12 Oct 2021

HAL is a multi-disciplinary open access archive for the deposit and dissemination of scientific research documents, whether they are published or not. The documents may come from teaching and research institutions in France or abroad, or from public or private research centers.
L'archive ouverte pluridisciplinaire HAL, est destinée au dépôt et à la diffusion de documents scientifiques de niveau recherche, publiés ou non, émanant des établissements d'enseignement et de recherche français ou étrangers, des laboratoires publics ou privés. 


\section{Shnaider V. Svetlana ${ }^{\mathrm{a}, \mathrm{b},{ }^{, *}}$, Alisher kyzy Saltanat ${ }^{\mathrm{a}}$, Tamara A. Yanina ${ }^{\mathrm{c}, \mathrm{d}}$, Bujilova Alexandra ${ }^{\mathrm{c}}$, Berezina Natalia ${ }^{c}$, Rigaud Solange ${ }^{\text {e,* }}$}

a Institute of Archaeology and Ethnography of the Siberian Branch of the Russian Academy of Sciences, 17, Acad. Lavrentiev avenue, Novosibirsk 630090, Russia b ArchaeoZOOlogy in Siberia and Central Asia - ZooSCAn, , CNRS - Institute of Archaeology and Ethnography SB RAS International Research Laboratory RU, 17, Acad. Lavrentiev avenue, Novosibirsk 630090, Russia

'M.V.Lomonosov Moscow State University, Mokhovaya 11, Moscow 125009, Russia d Institute of Geography RAS,

Staromonetny, 29, 119017 Moscow, Russia ${ }^{\mathrm{C}}$ CNRS, UMR 5199 - PACEA, Universit'e de Bordeaux, Batiment B8, All ${ }^{\wedge}$

'ee Geoffroy Saint Hilaire, 33615 Pessac, France

\section{ARTICLEINFO}

Keywords:

Central Asia

Eastern Caspian Early

Holocene

Paleogeography

Shell beads

Lithic industry

\begin{abstract}
A B STRACT
The southeastern Caspian region was an important migration route that connected ancient cultures between the Middle East and Central Asia. Currently, the only stratified sites known in the region are Dam-Dam-Cheshme 1, Dam-Dam-Cheshme 2, and Djebel in the Bolshoi Balkhan Region; and Kuba-Sengir and Kaylu on the Krasnovodsk Peninsula. In this article we review the archaeological materials from the Kaylu and Kuba-Sengir sites, which include prismatic and pressure bladelet industries respectively, faunal remains, and two distinct sets of shell bead industries. In addition two human burials were also previously discovered next to the entrance of Kaylu cave. During an excursion to the Krasnovodsk Peninsula in 2018, the geographic position of these sites was confirmed and materials discoverd on the surface during a survey of both sites were described. These preliminary data supports the idea that the Kuba-Sengir and Kaylu sites are asynchronous and share features with the southern, western and eastern Caspian sites which future research can use to further recreate the ancient population and cultural history of the greater Caspian region.
\end{abstract}

\section{Introduction}

During the unstable climatic conditions of the Quaternary period, the different transgression/regression episodes of the Caspian Sea played a major role in shaping the topography of the surroudning region, alternatively closing or opening potential past migration routes for ancient populations. Because of its central geographic location, between Central Asia and the Middle East, the area around the Caspian Sea likely represented a key crossroads for the diffusion of technological innovations between neighboring regions at different periods in time, from the arrival of the first modern humans into Eurasia up to the present day.

However, as a large part of the surrounding Caspian region has only been sporadically investigated, the history of human settlement on the eastern Caspian landscape is still poorly understood. Despite previous field investigations conducted during the mid-20th century by Okladnikov (1953a, 1953b, 1966) and Markov (1966), the current archaeological record of the eastern Caspian landscape suffers from the absence of an absolute chronology and a lack of global reassessment with modern methods necessary for better understanding past human cultural trajectories in the region. This patchy and imprecise record currently prevents important discussions regarding how the local environment, and more specifically changes in sea level, played a major role in human settlement dynamics and other aspects of the peopling of the Caspian region.

For this reason, we have proposed a project that relies on new excavation campaigns in western Turkmenistan in order to reassess the regional archeostratigaphy and clarify the geomorphological context of human settlement in the area. We have also reviewed the archaeological assemblages from multistratified sites excavated by Okladnikov in the Bolshoi Balkhan region (Dam-Dam-Cheshme 1, Dam-Dam-Cheshme 2, 


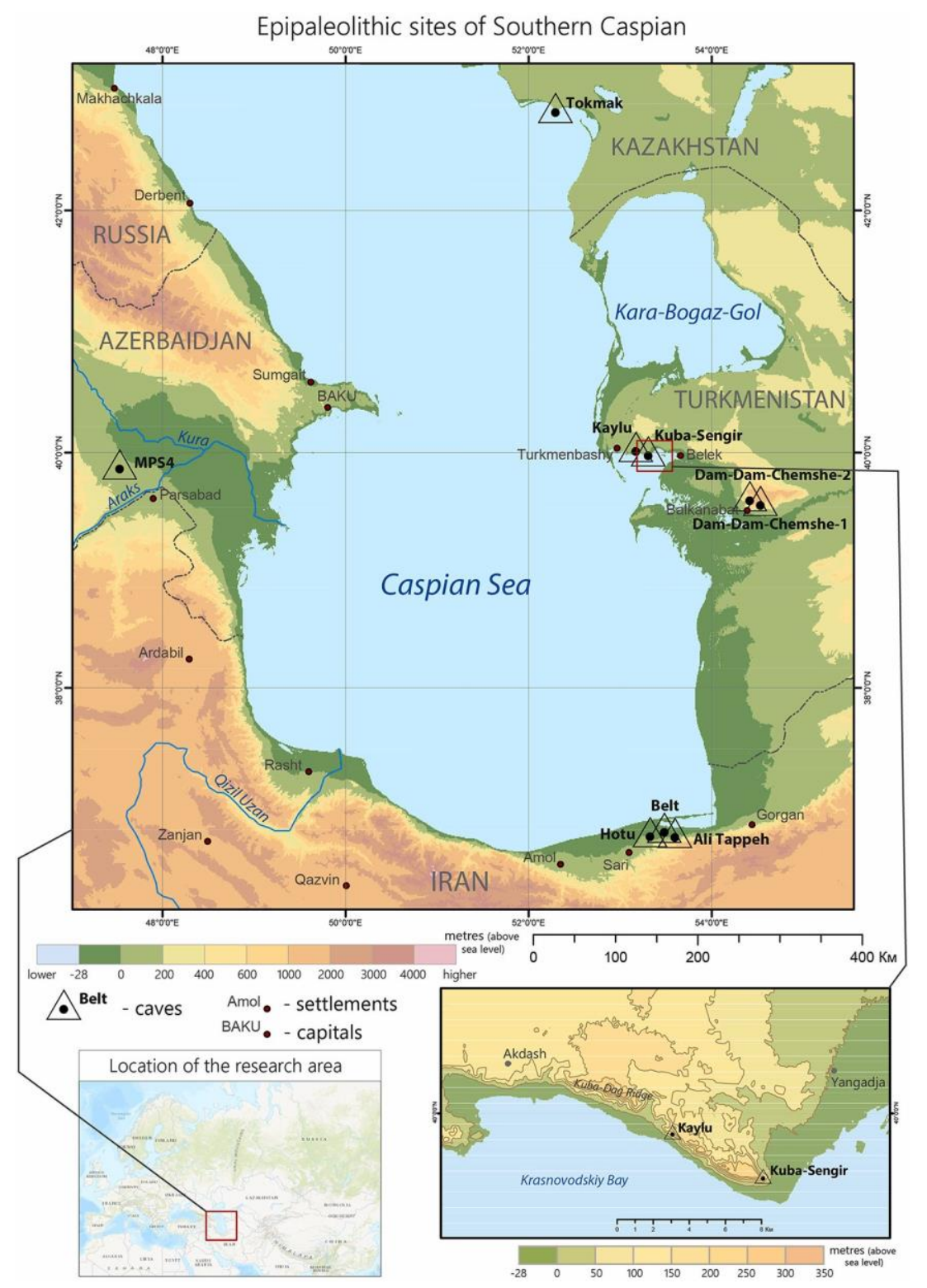

Fig. 1. Location of the archaeological sites mentioned in the article.

Djebel) and the Krasnovodsk Peninsula (Kuba-Sengir and Kaylu)

(Fig. 1). These sites have yielded a large collection of lithic artifacts, and human remains and one of the largest assemblages of shell beads in the region.

During the 2018 field season we conducted archaeological surveys on the Krasnovodsk Peninsula in western Turkmenistan, during which we identified the exact location of the Kuba-Sengir and Kaylu sites, recorded their geomorphological context, and collected samples for luminescence dating. With this field data we aimed to identify how changes in sea level in the Caspian Sea basin transformed the local environment and affected the rhythm and pattern of human dispersals during the terminal Pleistocene-early Holocene transition. In this article we revise the material from the excavations of Okladnikov, 1949, 1953a and present our new collections from the 2018 field season.

\section{Reevaluating the regional archaeological and geological context of Kaylu and Kuba-Sengir}

Kaylu and Kuba-Sengir are located at the eastern end of the Kubadag, an asymmetrical ridge with a deep precipice $(300 \mathrm{~m})$ within the Krasnovodsk Plateau. This ridge forms the northern wing of the large folded system of the
Kubadag-the Bolshoi Balkhans-which is composed of Jurassic limestone, dolomite and sandstone deposits. The Kubadag cliffs are characterized by a stepped landscape below and exhibit a series of horizontal ancient wave-cut shorelines as well as other evidence for past inland marine erosion that developed during the Quaternary transgressions of the Caspian Sea.

\section{Kuba-Sengir site setting and industry}

Kuba-Sengir is an open-air site located at the westernmost end of the Kubadag ridge on the remnant of the ancient structural terrace located at 14 masl (Fig. 2). A depression filled with sandy loam was excavated by Okladnikov which led to the discovery of stone artifacts, bones, and shells.

Most of the artifacts from Kuba-Sengir were found during the 1950 expedition (Okladnikov, 1953a), in a reddish stratigraphic unit, at a shallow depth. Within the archaeological assemblage a limited amount of faunal remains and 582 lithic artifacts were identified (Table 1). The lithic component of the assemblage includes a representative pressure 


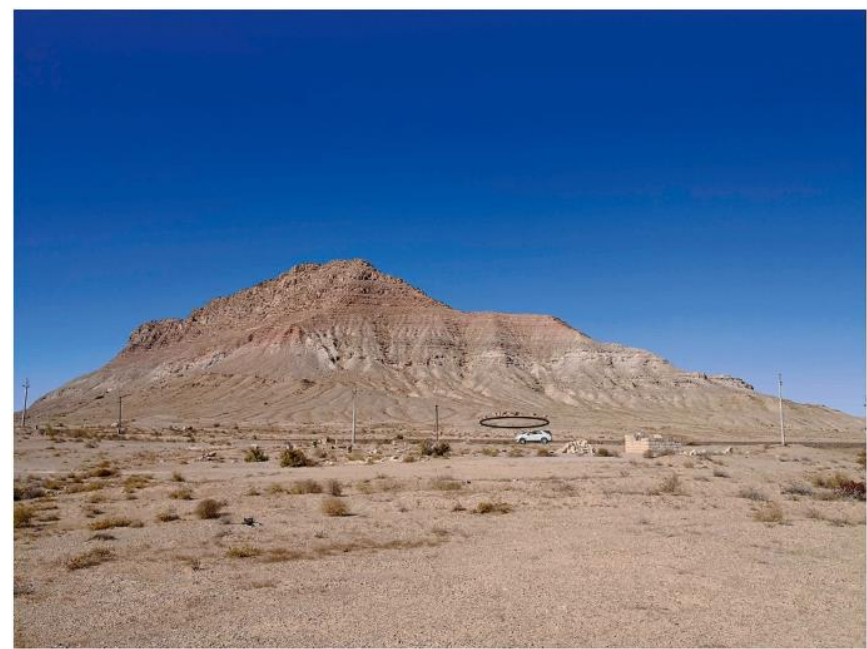

Fig. 2. General views of the Kuba-Sengir site (black oval shows the location of the site).

Table 1

Lithic industry from the Kuba-Sengir site.

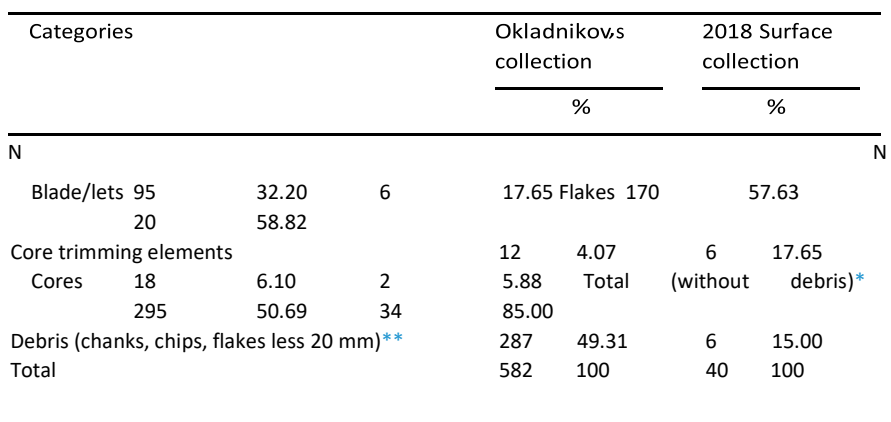

\footnotetext{
* Percentage of the total number of artifacts from layers without debris. ${ }^{* *}$
} Percentage of the total number of artifacts in the layer.

microblades industry, including volumetric bladelets cores, small backed points, backed bladelets, and scalene triangles (Fig. 3). Based on technotypological similarities between the Bolshoi Balkhan and southern Caspian lithic industries, the Kuba-Sengir assemblage was attributed to the late Mesolithic-early Neolithic period (Okladnikov, 1966). (See Table 2.)

More than 900 shell beads were recovered associated with the lithic industry at Kuba-Sengir (Fig. 4). Due to this exceptional concentration of personal ornaments, A.P. Okladnikov inteprated the site as a shell bead workshop (Okladnikov, 1953a).

In 2018, we collected surface artifacts from the southern part of the site. The material shows a strong similarity with Okladnikov's collections. We identified 14 additional shell beads and 40 lithic artifacts, including backed bladelets, notched pieces, and scalene triangles.

\section{Kaylu site setting and industry}

Five $\mathrm{km}$ to the west, the Kaylu cave is located in the lower part of the Kubadag cliff at an altitude of -4 masl (Fig. 5). The cave has a high ceiling and penetrates $4 \mathrm{~m}$ into the rock. The slope of the cliff is stepped and the cave entrance passes to a narrow terrace-like surface covered in sand and silt. The most significant findings were made in a test pit excavated by Okladnikov at the cave entrance.

Seven cultural layers were identified in the excavation area by Okladnikov (1951). The richest layer delivered a large lithic collection (208 items), bones $(n=135)$, and shell $(n=46)$ remains. The lithic collection is characterized by a prismatic knapping industry, involving the production of microlithics, notched tools, and end-scrapers (Fig. 6).
Two burials were discovered in close proximity to the cave site (Okladnikov, 1953b). The skeletons were oriented northwest, covered with ochre, and were associated with 175 discoid shell beads (Fig. 7). One flake, and several bones and ceramics were found during the recent surface survey of the site.

\section{Discussion and future research}

The history of the Caspian Sea during the terminal Pleistocene and the Holocene is characterized by sea level fluctuations, which include the stage of Early Khvalinian transgression (up to $+35 \mathrm{~m} \mathrm{~m}$ asl), the Late Khvalinian transgression (up to $0 \mathrm{~m}$ ), the Mangyshlak regression (-90 $\mathrm{m}$ ), and the New Caspian transgression (up to $-20 \mathrm{~m}$ ), with several stages of various magnitude (Svitoch, 2010; Arslanov et al., 2016; Bezrodnykh and Sorokin, 2016; Yanina et al., 2018; Kurbanov et al., 2021). The current altitude of the two sites is - 14 masl for Kuba-Sengir and -4 masl for Kaylu. During the major part of the Khvalinian period, the Krasnovodsk Peninsula was flooded, with the maximum level of the Late Khvalinian episode corresponding to $0 \mathrm{~m}$. This implies that human occupation at Kaylu and Kuba-Sengir could only have happened after the Late Khvalinian episode during the Early Holocene (in its Preboreal period, Svitoch, 2010).

Considerably more land became available during the gradual sea level decrease corresponding to the Mangyshlak regression (Boreal period, second half of the Early Holocene). The disappearance of water barriers and the formation of natural drainage systems (such as the Uzboy Valley) would have enabled active human migrations into and through the area. Recent data identifies four different transgressive phases during the Holocene (8000-5600 cal BP, 3600-3400 cal BP, 2000-1100 cal BP, and 900--60 cal BP, Bezrodnykh et al., 2020), corresponding to humid intervals suitable for human settlement. A relatively high humidity and proximity to the sea during these transgression episodes, which did not exceed - $20 \mathrm{~m}$, would have offered favorable conditions for human settlement in the region at Kaylu and Kuba-Sengir.

Kuba-Sengir (altitude - $14 \mathrm{~m}$ ) was possibly occupied after this decrease in sea-level of the Caspian during the Late Khvalinian episode. The presence of numerous fish bones, including sturgeon, and autochtonous shell species (Didacna cf. praetrigonoides Nal. et Anis., Didacna cf. subcatillus Andrus.), suggests that the site was still in close proximity to the sea. During the site's occupation, a regional increase in precipitation (Kislov et al., 2014) may have favored stream formation, currently corresponding to a network of dry valleys.

The Kaylu and Kuba-Sengir sites were attributed to the Mesolithic and early Neolithic respectively by A.P. Okladnikov, based on lithic typological criteria (Okladnikov, 1966). The reevaluation of the lithic assemblages from these two sites, based on a techno-typological approach, shows two different traditions of lithic production. The Kaylu assemblage shows similarities with the materials of the Eastern Caspian sheltered sites (Dam-Dam-Cheshme 1 and 2), with a prismatic blade/bladelete industry and microliths such as lunates, triangles and trapezoids (Okladnikov, 1953a, 1953b; Alisher kyzy et al., 2020). The toolkit of the lithic industry at Kaylu includes notches/denticulates, scrapers of all forms, especially end-scrapers, borers and backed tools and share common techno-typological features with the Southern Caspian industries present in Ali-Tappeh, Belt, and Komishan sites (Iran) attributed to Mesolithic 12-10 cal. ka BP (McBurney, 1964; Jayez and Vahdati Nasab, 2016; Vahdati Nasab et al., 2020). Contrary to Kaylu, the assemblage of Kuba-Sengir is associated with pressure microblade production. Its toolkit includes backed tools, scalene points, narrow triangles, microblades with ventral retouch, thumbnail-scrapers and bifacial narrow points. This industry can be compared to those of the hunter-fishers complexes of the Lower Uzboy and Oyuklin, dated 9-7 kaBP (Korobkova, 1996) and to the Neolithic assemblage from Koshimian cave (Vahdati Nasab et al., 2020). Thus, the use of soft hammer knapping technique during the Mesolithic and the pressure technique during the Neolithic (Leroy et al., 2019) appears to be a common trend 

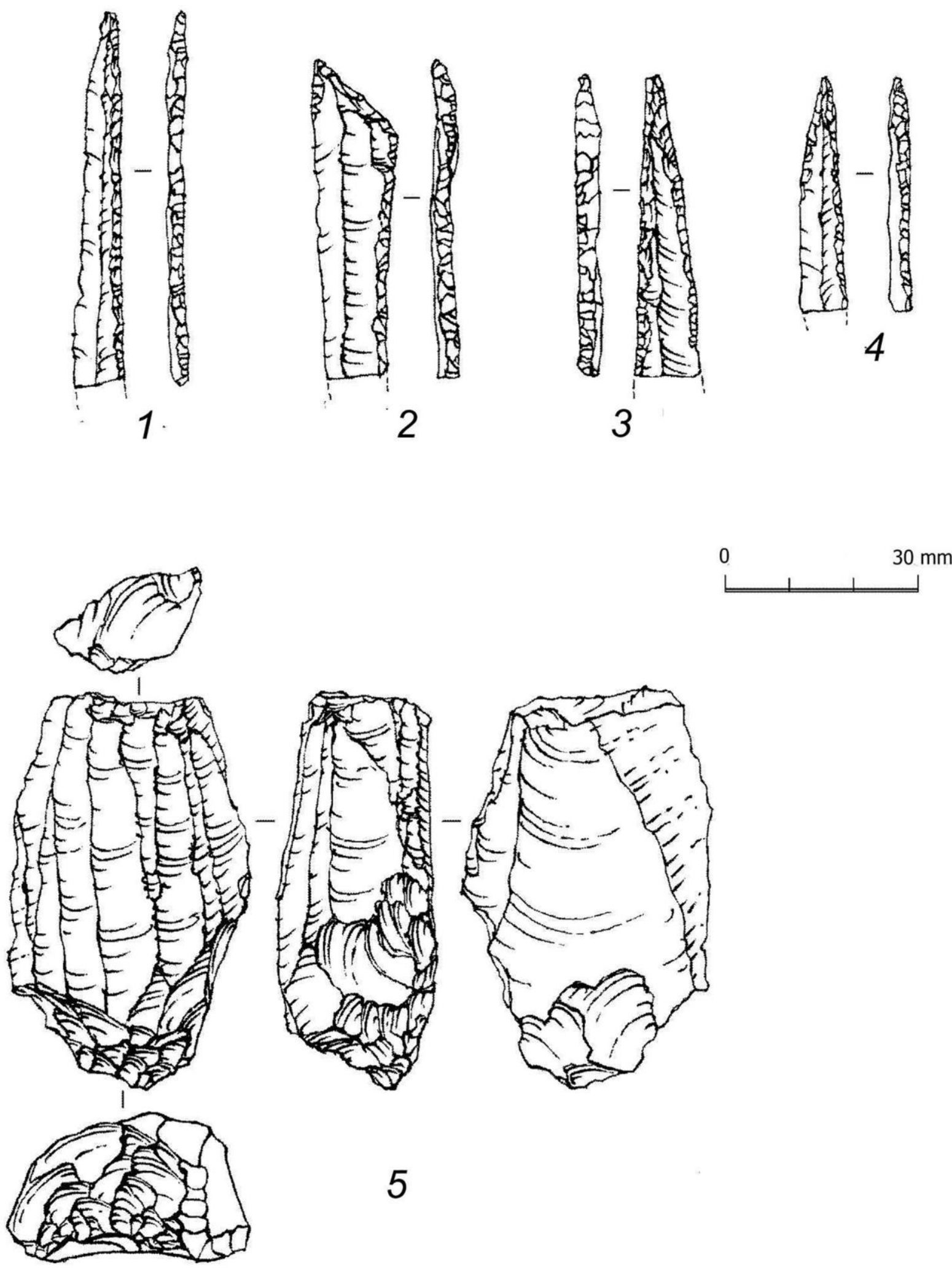

Fig. 3. Lithic industry discovered at Kuba-Sengir: 1-4) points; 5) core.

Table 2

Debris (chanks, chips, flakes less $20 \mathrm{~mm}$ )**

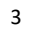

1.44

Lithic industry from the Kaylu site.

\begin{tabular}{lll}
\hline Categories & Layer 7 & \\
\cline { 2 - 3 } & & $\%$ \\
\hline
\end{tabular}

Total

208

100

Blade/lets 6732.68 Flakes

8943.41 Core trimming elements 4622.44

Cores $\quad 31.46$ Total (without debris)* 20598.56

* Percentage of the total number of artifacts from layers without debris. ${ }^{* *}$ Percentage of the total number of artifacts in the layer. 
between the eastern and the southern Capsian regions. The changes appearing during the Meso-Neolithic transition have been recently documented by the Koshimian cave stratigraphy (Vahdati Nasab et al., 2020). The earliest evidence of pressure based lithic technology in Central Asia dates back to 13 kaBP (Motuzaite et al., 2017) and during the Early Holocene we see a broad spread of this technology in the region (Brunet, 2002; Brunet, 2012). The technotypological similarities between Kuba-Sengir with nearby settlements along the Uzboy Valley and in the Kopetdag piedmont zone (Okladnikov, 1966), and with South Caspian assembalges allowed to us to hipothesize that Kuba-Sengir may have played an important role in the diffusion of the pressure technique from East to West.

However, the beads recovered from the Kaylu burials and from the workshop at Kuba-Sengir drastically differ from other regional Epipaleolithic shell remains (Manca et al., 2018; Okladnikov, 1953a, 1953b). At both sites, the shells belong to species native to the Caspian Sea and were most likely locally acquired by the local groups. The shell beads from Kaylu show typological and technological similaritites with the personal ornaments documented from the Chalcolithic cemetery at Tokmak (Kazakhstan; Astafiev, 2014) and the Early Neolithic site MPS 4 (Azerbaijan; Heit, 2014), but no correspondence has been found with the material from Kuba-Sengir. The Early occupation identified at Kaylu cave (layer 7), the two burials (Kaylu), and the bead workshop (Kuba- Sengir)-are therefore probably asynchronous as previously suggested by Okladnikov (1966).

The Krasnovodsk peninsula appears to have been exploited by humans since the Early Holocene as attested by Kaylu cave, layer 7. During the second half of the Early Holocene, human occupartion of the region is attested by Kuba-Sengir and during the Middle Holocene by the Kaylu burials. The common evolution of the lithic industries from Eastern and Southern Caspian suggests that between the two regions cultural contact was maintained during the Holocene. The burials suggest that the region was occupied in later periods. Recent palynological and sedimentary data from two lagoon cores obtained from southern coastal plain of the Caspian Sea in Iran (Leroy et al., 2019) demonstrates that the cool and dry climatic conditions often associated with the Younger Dryas stadial do not appear to have been extreme in this region. Thus, increasingly sedentary hunting and gathering groups could have drawn on plant and animal resources from multiple ecological niches without suffering significant resource stress or reduced population levels that may have been encountered in neighboring regions. It is likely that these environmental conditions favored a long and continuous process of residency in the Southern Caspian region until the Early Holocene. Further technological and functional data will provide new insights on the cultural mechanisms that influence diachronic variation in the production of artifacts made by the different groups who occupied this area during the Early Holocene.

\section{Declaration of Competing Interest}

This original research paper has not been published elsewhere and is not under consideration by any other journal. We do not foresee any conflict of interest in publishing this paper. Please contact the corresponding author if you require further information on this manuscript. We thank the editorial board for considering our manuscript for peer review.

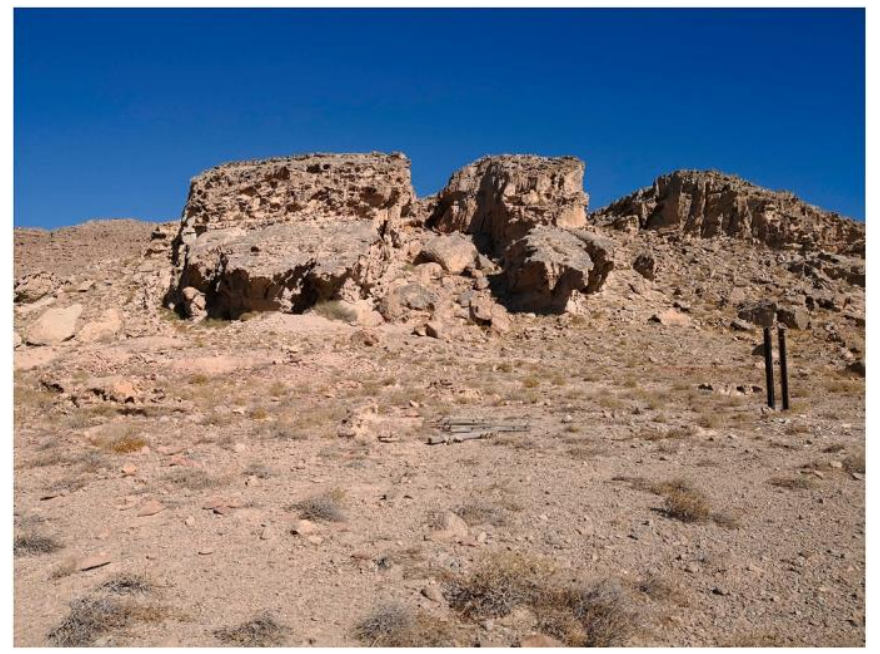

Fig. 5. General view of the Kaylu site.
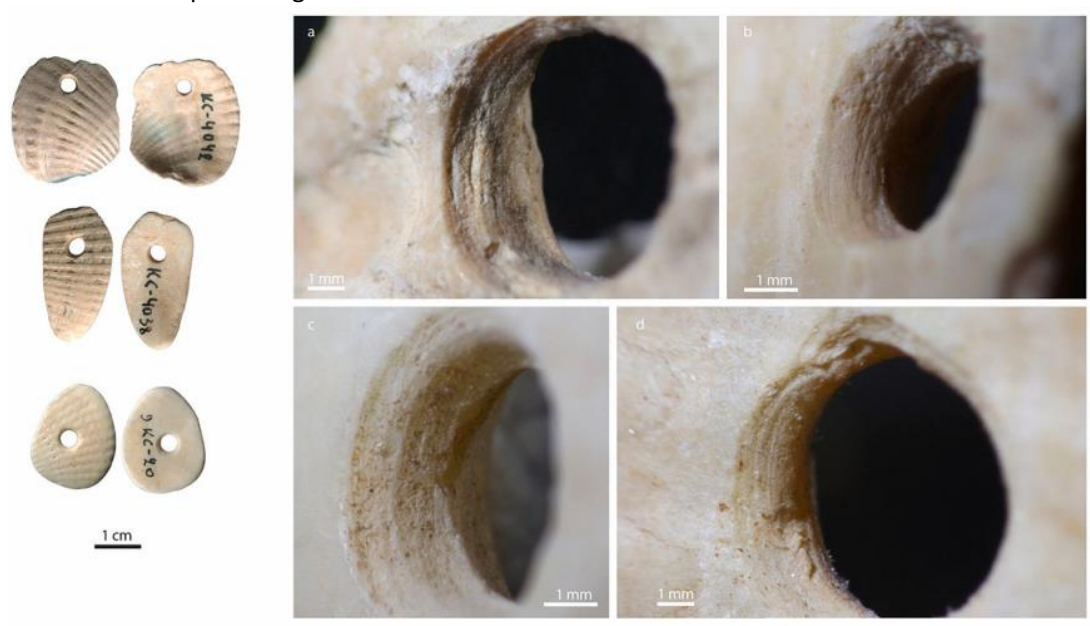

Fig. 4. : Shell beads discovered at Kuba-Sengir: a-d) circular parallel striations attesting to perforation by rotary motions. 

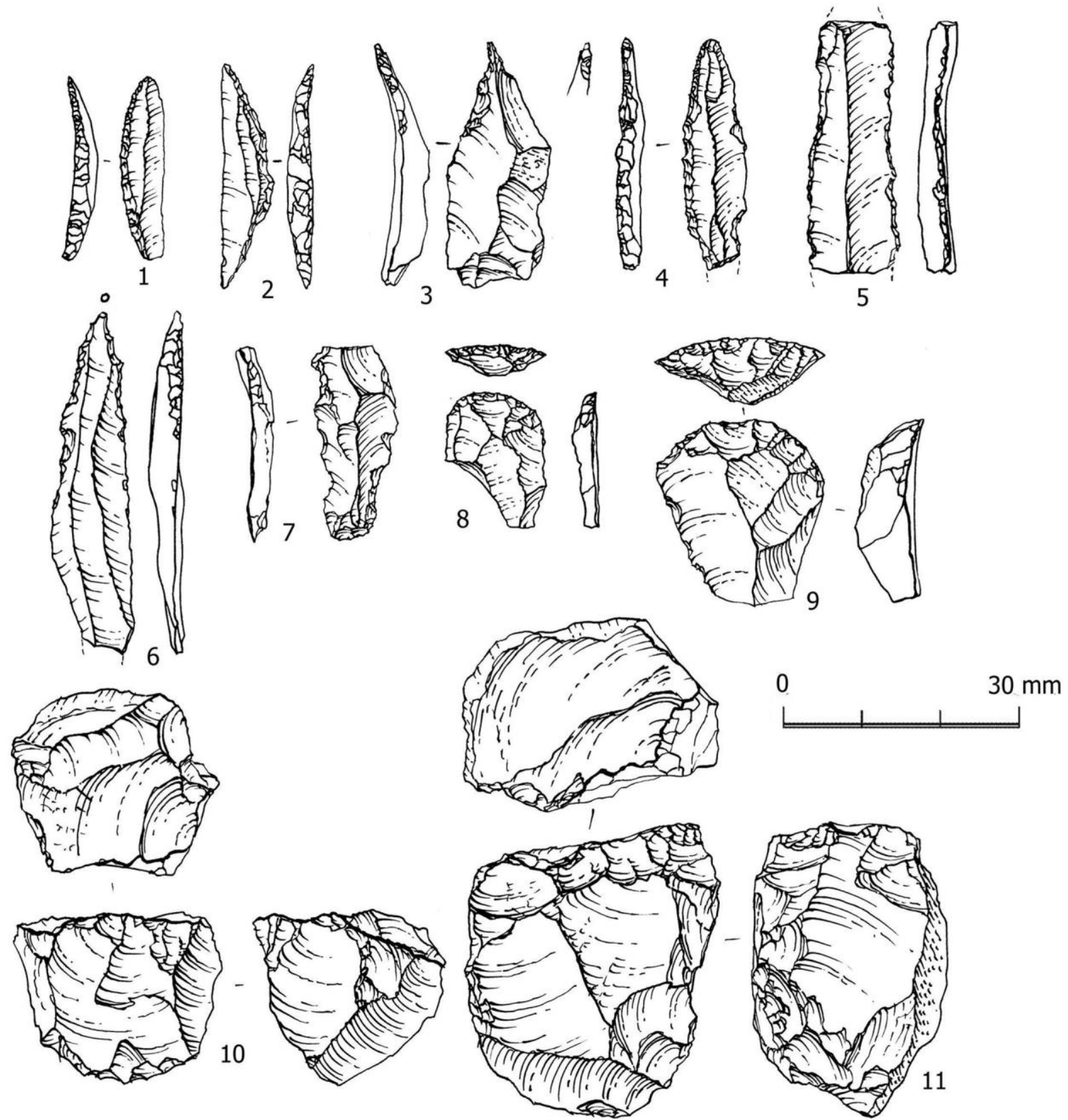

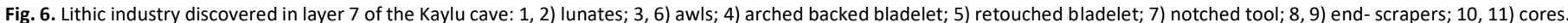




\section{1)

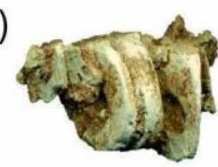

2)
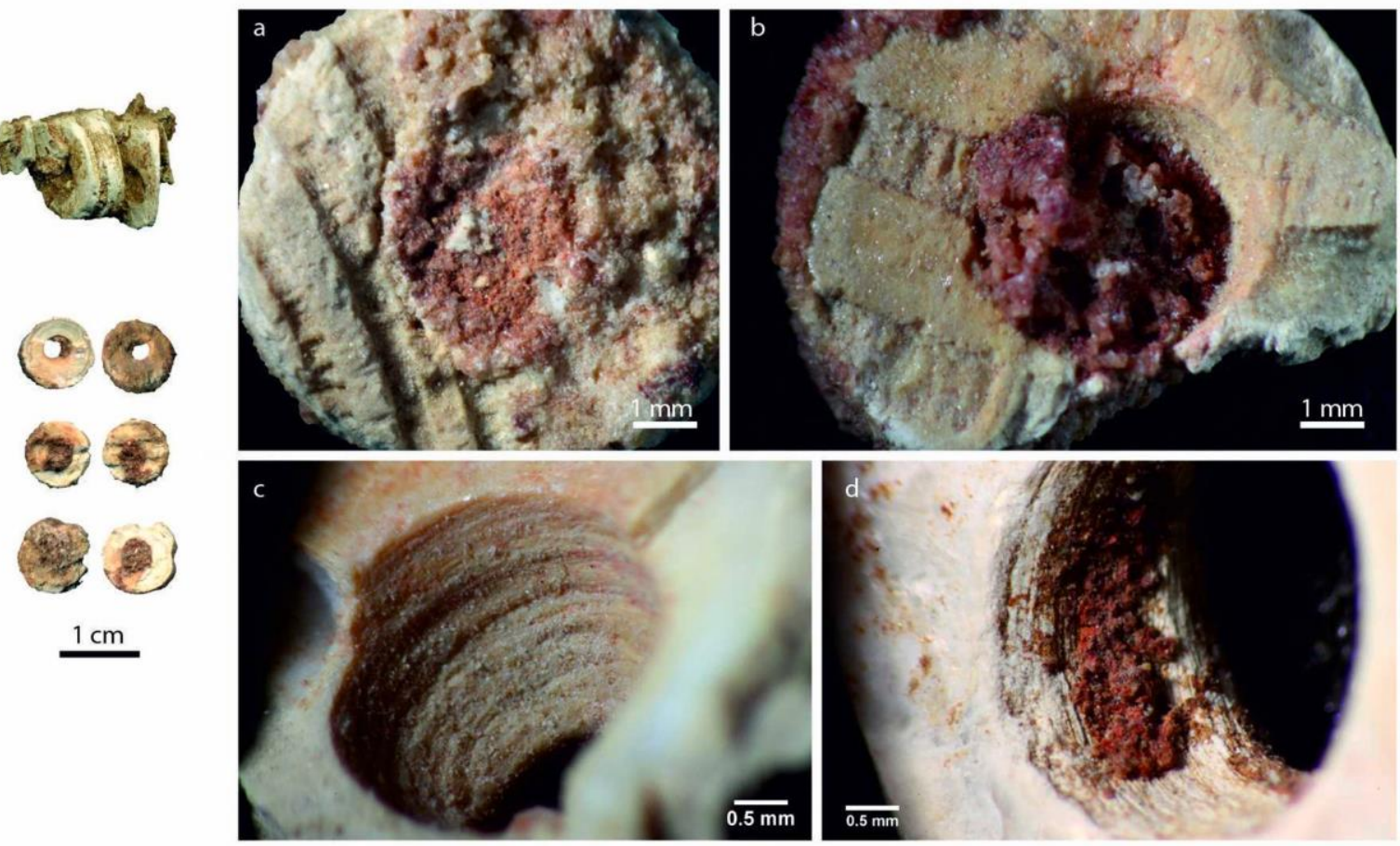

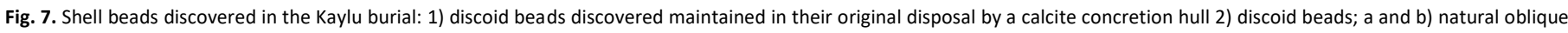

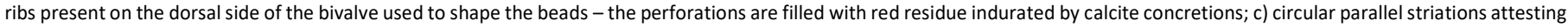

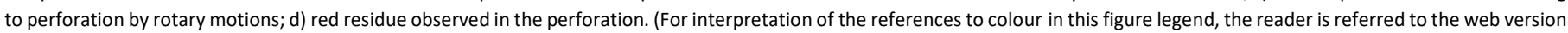
of this article.)

\section{Acknowledgements}

We greatly appreciate the Russian Foundation for Basic Research's financial support N-20-39-70020, N-19-39-90052, and R\&D Project No. 02642019-0009. This work was also supported by the French National Research Agency under the IDEX Bordeaux NETAWA Emergence project no. ANR-10IDEX-03-02 'Out of the Core: Exploring social NETworks at the dawn of Agriculture in Western Asia 10000 years ago', the French-Russian CNRS International Laboratory "Multidisciplinary Research on Prehistoric Art in Eurasia - ARTEMIR", and the GPR (Grand Programme de Recherche) 'Human Past' of the University of Bordeaux's Initiative d'Excellence". We wish to convey a special thanks to our colleague in the M.V. Lomonosov Moscow State University Dr. Kurbanov R.N. for his assistance, collegiality and friendship over many years. We are grateful to Corey L. Johnson from University of California-Davis for English corrections and we are thankful to reviewers for their comments and suggestions. References

Alisher kyzy, S., Shnaider, S.V., Kolobova, K.A., Krivoshapkin, A.I., 2020. New data on the mesolithic of Eastern Caspian: lithic industry of dam-dam-Cheshme-2 site (based on A. P. Okladnikov's materials). Stratum plus. Archaeol. Cult. Anthro. 1, 257-278.

Arslanov, Kh.A., Yanina, T.A., Chepalyga, A.L., Svitoch, A.A., Makshaev, R.R.,

Maksimov, F.E., Chernov, S.B., Tertychniy, N.I., Starikova, A.A., 2016. On the age of the Khvalynian deposits of the Caspian Sea coasts according to $14 \mathrm{C}$ and $230 \mathrm{Th} / 234 \mathrm{U}$ methods. Quat. Int. 409, 81-87. https://doi.org/10.1016/j.quaint.2015.05.067.

Astafiev, A.E., 2014. Neolithic and Chalcolithic of the Mangyshlak Peninsula. Series: Materials and Studies on the Kazakhstan Archaeology VI. Astana Branch of the Institute of Archaeology named after A. Kh. Margulan, Astana, p. 359.

Bezrodnykh, Yu.P., Sorokin, V.M., 2016. On the age of the Mangyshlakian deposits of the northern Caspian Sea. Quat. Res. 85 (2), 245-254. https://doi.org/10.1016/j. yqres.2016.01.004.

Bezrodnykh, Y., Yanina, T., Sorokin, V., Romanyuk, B., 2020. The northern Caspian Sea: consequences of climate change for level fluctuations during the Holocene. Quat. Int. 540, 68-77. https://doi.org/10.1016/j.quaint.2019.01.041.

Brunet, F., 2012. The technique of pressure knapping in Central Asia: Innovation or diffusion? In: Desrosiers, Pierre M. (Ed.), The Emergence of Pressure Blade Making.

From Origin to Modern Experementation. Springer, New York, pp. 307-328. https:// doi.org/10.1007/978-1-4614-2003-3_12.

Brunet, F., 2002. Asie centrale: Vers une red'efinition des complexes culturels de la fin du Pl'eistocene et des 'd'ebuts de l'Holocene. 'Pal'eorient. 28 (2), 9-24.

Heit, I., 2014. The bead workshop at site MPS4, mil plain, Azerbaijan: craft specialization and the manufacture of shell jewelry in the Neolithic. Polish Archaeol. Mediterran. 23 (2), 21-40.

Jayez, M., Vahdati Nasab, H., 2016. A separation: caspian mesolithic VS trialetian lithic industry. A research on the excavated site of komishan, southeast of the Caspian Sea, Iran. Paleorient 42 (1), 75-94.

Kislov, A.V., Panin, A., Toropov, P., 2014. Current status and palaeostages of the Caspian Sea as a potential evaluation tool for climate model simulations. Quat. Int. 345, 48-55. https://doi.org/10.1016/j.quaint.2014.05.014.

Korobkova, G.F., 1996. Srednyaya Aziya i Kazakhstan. In: Oshibkina, S.V. (Ed.), Neolit Severnoi Yevrazii. Nauka, Moscow, pp. 87-133.

Kurbanov, R., Murray, A., Thompson, W., et al., 2021. First reliable chronology for the early Khvalynian Caspian Sea transgression in the lower Volga river valley. Boreas. 50 (1), 134-146. https://doi.org/10.1111/bor.12478.

Leroy, S.A.G., Amini, A., Gregg, M.W., Marinova, E., Bendrey, R., Zha, Y., Naderi Beni, A., Fazeli Nashl, H., 2019. Human responses to environmental change on the southern coastal plain of the Caspian Sea during the Mesolithic and Neolithic periods. Quat. Sci. Rev. 218, 343364. https://doi.org/10.1016/j. quascirev.2019.06.038.

Manca, L., Mashkour, M., Shidrang, S., Averbouh, A., Biglari, F., 2018. Bone, shell tools and ornaments from the Epipalaeolithic site of Ali Tappeh, East of Alborz Range, Iran. J. Archaeol. Sci. Rep. 21, 137-157. https://doi.org/10.1016/j. jasrep.2018.06.023.

Markov, G.E., 1966. Grot Dam-Dam-Cheshme-2 v Vostochnom Prikaspii. Sovetskaia Arkheologiia. 2, 104-125.

McBurney, C.B.N., 1964. Preliminary report on stone age reconnaissance in North Eastern Iran. Proc. Prehistoric Soc. 30, 382-399. https://doi.org/10.1017/ S0079497X00015176.

Motuzaite, Matuzeviciute G., Preece, R.C., Wang, S., Colominas, L., Ohnuma, K., Kume, S., Abdykanova, A., Jones, M.K., 2017. Ecology and subsistence at the Mesolithic and Bronze Age site of Aigyrzhal-2, Naryn valley, Kyrgyzstan. Quat. Int. 437/B, 35-49. https://doi.org/10.1016/j.quaint.2015.06.065.

Okladnikov, A.P., 1949. Izuchenie drevneishikh arkheologicheskikh pamyatnikov Turkmenii. In: Kratkiye soobshcheniya instituta istorii i materialnoy kultury, Leningrad, 28, pp. 67-71.

Okladnikov, A.P., 1953a. Drevneishie archeologicheskie pamyatniki Krasnovodskogo poluostrova. In: Masson, M.E. (Ed.), Trudy JuzhnoTurkmenskoj arheologicheskoj ekspedicii, Ashgabad, pp. 73-104.

Okladnikov, A.P., 1953b. Izuchenie pamyatnikov kamennogo veka v Turkmenii (po dannym rabot IX otryada YUTAKE v 1952 g.). Izvestia AN TSSR 2, 3-22.

Okladnikov, A.P., 1966. Paleolit i mezolit Srednej Azii. In: Masson, V.M. (Ed.), Srednjaja Azija v epohu kamnja i bronzy. Nauka, Moscow- Leningrad, pp. 11-75.

Svitoch, A.A., 2010. The Neoeuxinian basin of the Black Sea and the Khvalinian transgression of the Caspian Sea. Quat. Int. 225, 230-234. https://doi.org/10.1016/ j.quaint.2009.03.005. Vahdati Nasab, H., Nikzad, M., Jayez, M., Hashemi, M., Knapp, Z., Sykes, N., Zarehkhalili, M., Ilkhanimoghaddam, H., Bakhtiarinasab, F., Olszewski, D.I., 2020. 
Komishan cave: a mesolithic and later settlement on the southeastern shore of the Caspian Sea, Iran. Anes. 57, 97-125. https://doi.org/10.2143/ANES.57.0.3288614.

Yanina, T., Sorokin, V., Bezrodnykh, Yu., Romanyuk, B., 2018. Late Pleistocene climatic events reflected in the Caspian Sea geological history (based on drilling data). Quat. Int. 465, 130141. https://doi.org/10.1016/j.quaint.2017.08.003. 